James Dechant

Boston College

School of Theology and Ministry

\title{
Rehabilitation for the Paralytic Man? \\ John 5 and an Aesthetics of Ambiguity
}

Within the narrative of the Fourth Gospel, the healing episode in chapter 5 creates division and danger. At the center of this unfortunate sequence lies an unnamed paralytic man, whom one commentator calls "one of the least defined characters in the Gospel."1 In fact, the actions of this particular character seem open to conflicting interpretations. In this essay, I will argue that ambiguity is an intentional feature of John's narrative technique, written so as to create a condition of uncertainty in the reader. We are left with an undetermined experience of the text, allowing us to participate in the ambiguity experienced by the characters themselves. To show this, I want to first examine the story itself, then present some possible interpretations. Finally, I will conclude by gesturing at what this means for our reading of Scripture - what I'd like to call an "aesthetics of ambiguity."

\section{The story}

Set during an unnamed "festival of the Jews," this healing story opens with a description of the scene: "Now in Jerusalem by the Sheep Gate there is a pool, called in Hebrew Beth-zatha, which has five porticoes." "2 After noting the pool's function as a place of healing for the invalids who lay among the porticoes, the narrator zooms in on one unnamed man who "had been ill for thirty-eight years."

\footnotetext{
${ }^{1}$ R. Alan Culpepper, "John 5.1-18: A Sample of Narrative Critical Commentary," in The Gospel of John as Literature: An Anthology of Twentieth-century Perspectives, ed. Mark W.G. Stibbe (Leiden, N.Y.: E.J. Brill, 1993), 204.

${ }^{2}$ All Biblical quotations come from the NRSV.
} 
Jesus enters the scene and perceives that the man had been there "a long time." He asks the man, "Do you want to be made well?" The man responds indirectly, saying "Sir, I have no one to put me into the pool when the water is stirred up; and while I am making my way, someone else steps down ahead of me" (5:7). Jesus tells him, "Stand up, take your mat and walk." At once, the story continues, "the man was made well, and he took up his mat and began to walk."

So ends the miracle itself. But the story continues, revealing in 5:9 that it was the sabbath. The Jews accuse the man of violating the sabbath by performing work. He simply repeats what has happened: "The man who made me well said to me, 'Take up your mat and walk." When pressed for more details, the former-paralytic cannot supply Jesus' name. But later he encounters Jesus in the temple, receives a warning to sin no more, and returns to the Jews to reveal Jesus' identity. "Therefore," reads 5:16, "the Jews started persecuting Jesus, because he was doing such things on the sabbath.”

\section{Critical interpretations}

Interpretations of the man center around two points. First: is his response to Jesus' question evasive or does it help us pity him? Second: what do we make of the man's reporting Jesus' name to the Jews? Is it a bold witness, a sinister collaboration, or an ignorant mistake? Raymond Brown, one of the leading twentieth century Johannine scholars, has a wholly negative (though amusing) take:

[The man's] crotchety grumbling about the "whippersnappers" who outrace him to the water betrays a chronic inability to seize opportunity, a trait reflected again in his oblique response to Jesus' offer of a cure. The fact that he had let his benefactor slip away without even asking his name is another instance of real dullness. [...] Finally he repays his benefactor by reporting him to 'the Jews.' This is less an example of treachery ... than of persistent naivete. ${ }^{3}$

\footnotetext{
${ }^{3}$ Raymond Brown, The Gospel According to John (Garden City, N.Y.: Doubleday, 1964), 1:209.
} 
Other commentaries concur with Brown's unsympathetic reading. Many say that readers cannot identify with the man ${ }^{4}$ or that the man only moves from being physically to spiritually crippled. ${ }^{5}$

Yet not everyone is on board with Brown and company's reading of this scene. Some commentators have noticed how the story dramatically reveals it was the sabbath only after the healing is complete. ${ }^{6}$ Perhaps this narrative flourish is meant to invite reinterpretation of the man, who, after all, unquestioningly obeyed Jesus' command to carry his mat. Is he not a risk-taker? And we should not forget that the scene takes place during a festival. The man's presence at the pool rather than the Temple - where most non-disabled males would be - already foregrounds the theme of social division. ${ }^{7}$ Certainly the man's apparent lack of friends, neighbors, or helpers casts him as a marginal member of society. Suddenly all the negative analyses begin to sound rather cold and callous, with little sympathy for the man's deplorable situation, little thought to what it says about his community. Yet this reading is also tenuous, because we don't know what finally happens to the man. After verse 15, he disappears from the story.

\section{Toward an aesthetics of ambiguity}

The lack of definitive closure to this character creates a cognitive gap for the reader. We have the challenge (and pleasure) of filling in this gap and confronting the same questions as the character - i.e., what is this new reality? Narrative ambiguity thus provokes a response that clear certainty would restrict; it allows us to reckon the moral calculus without a predetermined

\footnotetext{
${ }^{4}$ Francis J. Moloney, The Gospel of John (Collegeville, Minn.: Liturgical Press, 1998), 169-73.

${ }^{5}$ Culpepper, 204-205.

${ }^{6}$ See for example J.L. Staley, "Stumbling in the Dark, Reaching for the Light: Reading Character in John 5 and John 9," Semeia 53 (1991): 55-80.

${ }^{7}$ The Mishnah - the collection of rabbinic teachings clarifying the laws of the Torah - exempted males with a disability from the obligation to visit Jerusalem during certain festivals. Of course, it is not clear if the evangelist has such a festival in mind. See Patricia Bruce, "John 5:1-18: The Healing at the Pool: Some Narrative, Socio-Historical, and Ethical Issues,” Neotestamentica 39:1 (January 2005): 39-56.
} 
outcome, to join the character in a condition of uncertainty. Our struggle to interpret the man's post-healing actions is not unlike his own struggle to comprehend his new state.

This interpretive act draws us into a process of discernment. We have no choice but to go through the mental legwork of judging how characters meet Johannine ideals and/or fall short. In the process, we can hold a mirror up to our own behavior. ${ }^{8}$ The nuanced portrayal of the man in John 5 shows a rounded, complex life of faith, which should warn us against flattening our own lives into simplified, unambiguous portrayals. ${ }^{9}$ Faith is dynamic, not static. In Greek, this Gospel always uses belief as an active verb, ${ }^{10}$ highlighting that the encounter with Jesus is an ongoing relationship, a dialogue that changes each time we come to it, just as we change and grow.

Now, it may seem strange to talk about ambiguity or dynamic faith in the Gospel of John. If you read it through, you know what I mean: it paints a stark contrast between those who accept the Word of God and those who reject it, between the children of light and the children of the devil. But while the evangelist may expect our faith-response to be clear, that does not mean it will come all at once. Nor does it mean that our experience of the text will be unambiguous.

If, as scholars like Sandra Schneiders argue, appropriation is central to the work of Biblical interpretation, then recognizing the inherent ambiguity in Johannine characters helps to prioritize the process of making text-to-self connections. We cannot help but relate it to our own lives. This is a personalized hermeneutic, and a demanding one: we cannot be content with a single reading of a rich text like John. Nor can we outsource the work of interpretation to commentators. Their attempts to resolve the indeterminacy of characters deprive the reader of

\footnotetext{
${ }^{8}$ Susan Hylen, Imperfect Believers: Ambiguous Characters in the Gospel of John (Louisville, KY: Westminster John Knox Press, 2009), 161.

9 Colleen M. Conway,"Speaking Through Ambiguity: Minor Characters in the Fourth Gospel," Biblical Interpretation 10:3 (2002), 340-41.

${ }^{10}$ Sandra Schneiders, Written That You May Believe: Encountering Jesus in the Fourth Gospel (New York: Crossroads, 2003), 11-12.
} 
some of the text's meaning, for meaning "is not exhausted by a text's content, but is created anew as each reader becomes actively engaged with the text." ${ }^{" 11}$ We have to wrestle with the contours of Johannine faith ourselves. The Gospel functions as a spiritual text not when we dissect it and confidently map each character's trajectory, but rather when we allow it to inform our lives and factor in to our decisions. Ambiguity actually fosters an openness to the text's transformative power.

An aesthetics of ambiguity, then, sees ambiguity not as an obstacle to be overcome but a meaningful encounter with the text that we should welcome. It ensures that our faith response will not be predetermined. Ambiguity helps readers to enter into the faith lives of characters and, in turn, to foster a sense of their own ongoing encounter with the Word. By renouncing certainty, we open ourselves up to a potentially more transformative encounter.

So the inscrutability of the paralytic man should not frustrate us; it should affirm our own struggle to respond appropriately to radical new realities. And when we are transformed by some unforeseen and undeserved grace, the best response we can muster may be nothing more than a dumb repetition of the events transpired. The important thing is that, when called, we stand up and walk.

\footnotetext{
${ }^{11}$ Jouette M. Bassler, "Mixed Signals: Nicodemus in the Fourth Gospel," Journal of Biblical Literature 108:4 (Winter 1989), 644.
} 